\title{
Мінеральні ресурси
}

doi: https://doi.org/10.15407/gpimo2019.01.003

\section{Е.Ф. Шнюков}

ГНУ «Центр проблем морской геологии, экологии

и осадочного рудообразования» НАН Украины, Киев

\section{ЧEPHOE MOPE: БУДУЩЕЕ МИНЕРАЛЬНО-СЫРЬЕВОЙ БАЗЫ}

В статье рассматриваются возможные пути геологического изучения и освоения минерально-сырьевого комплекса Черного моря, в частности, энергетического комплекса, оолитовых железных руд, стройматериалов, минеральных удобрений, пресной воды, титаноциркониевых и магнетитовых россыпей, тонкого золота. Подчеркивается необходимость изучения и освоения газогидратов. Отмечена важность фундаментальных исследований для прикладной геологии, особенно изучения кристаллических пород Черного моря для понимания его геологической истории и строения.

Ключевые слова: Черное море, минерально-сырьевая база, сапропели, газогидраты метана, прибрежно-морские россыпи, тонкое золото.

Отец истории Геродот назвал Черное море самым замечательным из всех морей. Жизнь подтвердила его оценку. В наши дни это прекрасный курортный регион, на берегах которого отдыхают миллионы людей, узел транспортных коммуникаций, источник пищевых ресурсов. Несомненно, все это получит развитие в будущем.

Но главная стоящая перед нами задача - освоение мощного и многообразного минерально-сырьевого потенциала, дарованного нам природой. Пока мы в этом отношении не преуспели. Успехи есть, и значительные, но они не соответствуют тому потенциалу, которым обладает Азово-Черноморский бассейн. Ныне мы переживаем застой, обусловленный упадком промышленности. В этих условиях особенно важно понимать, какие богатства может подарить наше море, когда мы всерьез начнем его осваивать.

Несомненно, главным богатством являются его потенциальные энергетические ресурсы. Природа предъявила нам многочисленные факты их реальности и масштабности. Обнаружены на юго-востоке Черного моря значительные природные высачивания нефти близ турецкого города Ризе и мористее города Поти (Грузия). Найдено пока до 70 грязевых вулканов, являющихся индика-

(C) Е.Ф. ШНЮКОВ, 2019 


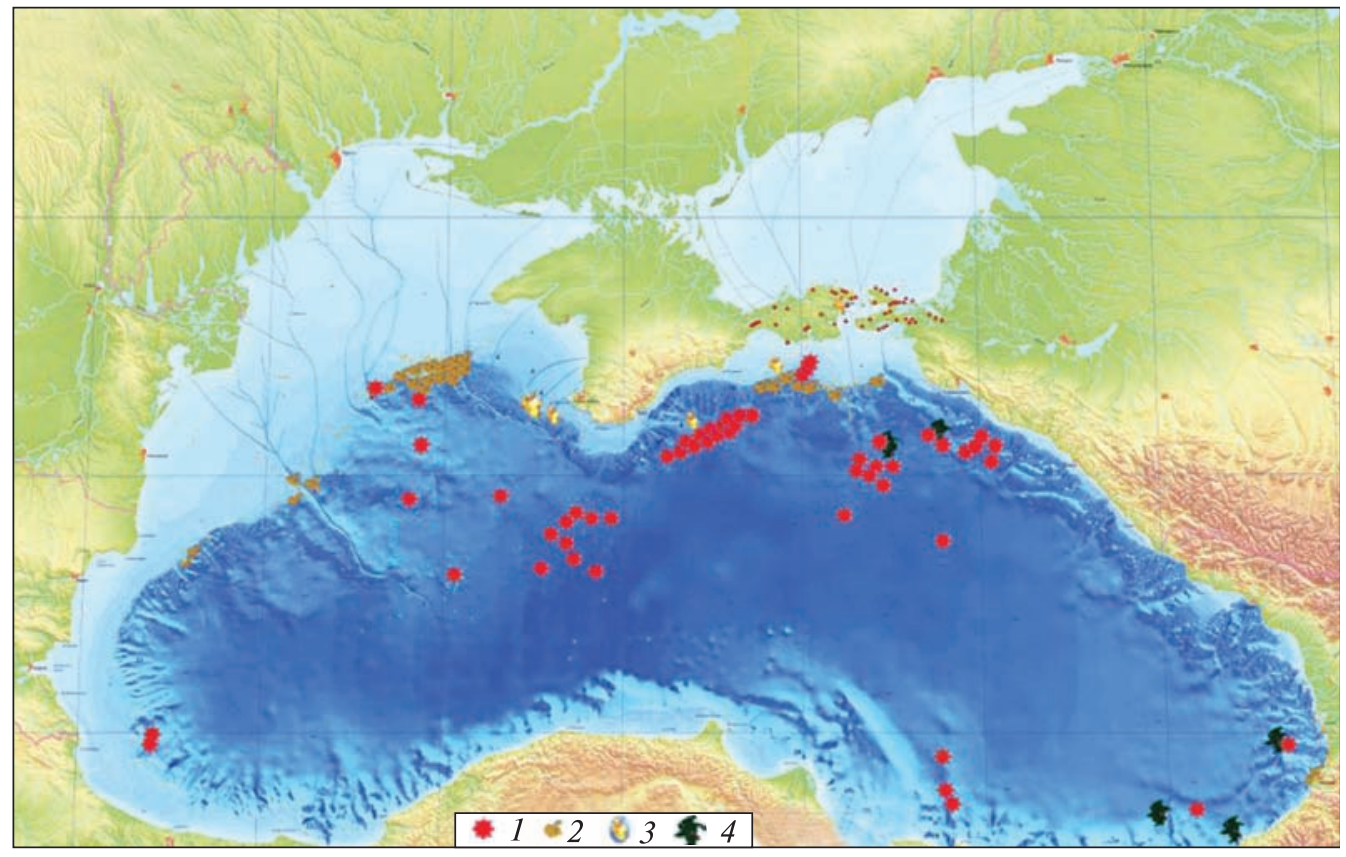

Puc. 1. Природные газовыделения на дне Черного моря: 1 - грязевые вулканы; 2 - вспышки газов во время землетрясений; 3 - основные скопления газовых сипов; 4 - природные высачивания нефти

торами нефтегазоносности недр, многие тысячи газовых факелов (рис. 1) [3]. Имели место катастрофические взрывы метана во время землетрясений в Керченском проливе (63 г до н.э., царствование Митридата), Крымского землетрясения (1928) и др. Гигантские выбросы, скорее всего метана, продолжались еще два месяца после землетрясения [7]. Суммарные объемы газовыделения с черноморского дна оцениваются цифрой 5-6 × $10^{9} \mathrm{~m}^{3}$ (данные Кесслера в [5]).

Начало геологических исследований моря в этой связи представляется совершенно оправданным. Первым из черноморских стран был СССР. В 1971 г. пробурена первая скважина на поднятии Голицына. Этому предшествовали большие геофизические работы. С тех пор пробурены скважины на северо-западе, прикерченском шельфе, в Азовском море, открыто 13 преимущественно небольших месторождений, часть из них освоена. Есть разные оценки запасов. По последним данным на 2017 г., Госгеонедр оценил потенциальные запасы газа на шельфе Черного моря цифрами от 80 до 300 млрд м ${ }^{3}$, а нефти 3,22 млн т. Оценить реальную добычу сейчас сложно из-за аннексии Крыма. Активы «Черноморнефтегаза» потеряны. Украина судится с Россией в Гаагском суде. По данным Интернета, «Укргаздобыча» все же планирует в Черном море через 5-7 лет выйти на уровень 5 млрд м ${ }^{3}$ в год. Геологическая служба морского поискового бурения не планирует.

Из всех черноморских стран наибольших успехов добилась Румыния. Здесь (данные на 2011 г.) пробурено 70 скважин, открыты 2 нефтяных и 12 газовых месторождений. На отданной В.А. Ющенко Олимпийской структуре (район южнее ова Змеиный) установлено 70 млрд м газа и 12 млн т нефти.

В Болгарии найдены два небольших газовых месторождения - Галата и Калиакра. Добыча 0,4 млрд м ${ }^{3}$ газа. 
В Турции работали многие ведущие компании - Эксон, Петробраз, ВР и др. Обнаружено 13 перспективных структур. Запасы не известны. Якобы ведется добыча на месторождениях Аязли и Аккая. В Грузии - только надежды.

В России проведены большие геофизические работы, выявлено 14 объектов, но только в одной структуре - Рифовой - пробурена скважина. Есть признаки нефти.

В целом, однако, масштабы открытий и добычи не соответствуют потенциалу моря, не удовлетворяют потребности и далеко не соответствуют надеждам и перспективам. По данным О.М. Русакова и Р.И. Кутаса [10], пробуренные десять последних глубоких скважин в Черном море оказались безрезультатными.

Внесу поправку к этим данным - одна из скважин - Домино-1 - в румынском секторе дала месторождение с запасами до 40 млрд м³ газа (данные Леончик, Сенина, Хортова, 2013) (рис. 2). Общей картины, однако, это не меняет. Нефтяные компании начинают перебазироваться в Восточное Средиземноморье, где получены хорошие результаты. Нам представляется, что нефтегазовый потенциал Черного моря заслуживает самого серьезного внимания. При этом нельзя не поддержать мнение О.М. Русакова и Р.И. Кутаса о том, что пора сменить парадигму поисков, оставить идеи органического происхождения нефти и перейти к другим представлениям о генезисе.

К главному богатству моря мы еще и не подступили. Главным богатством Черного моря являются газогидраты метана. О них много пишут, подсчитали даже потенциальные запасы. По данным разных авторов их от 25 трлн т до 48 трлн т. К этим подсчетам надо относиться с осторожностью. Зона гидратообразования локализована в глубоководной части Черного моря при глубинах более 600-650 м. Следует иметь в виду, что газогидраты не покрывают все дно Черного моря, а образуют два типа залежей: залежи на континентальном склоне и залежи вокруг гря-

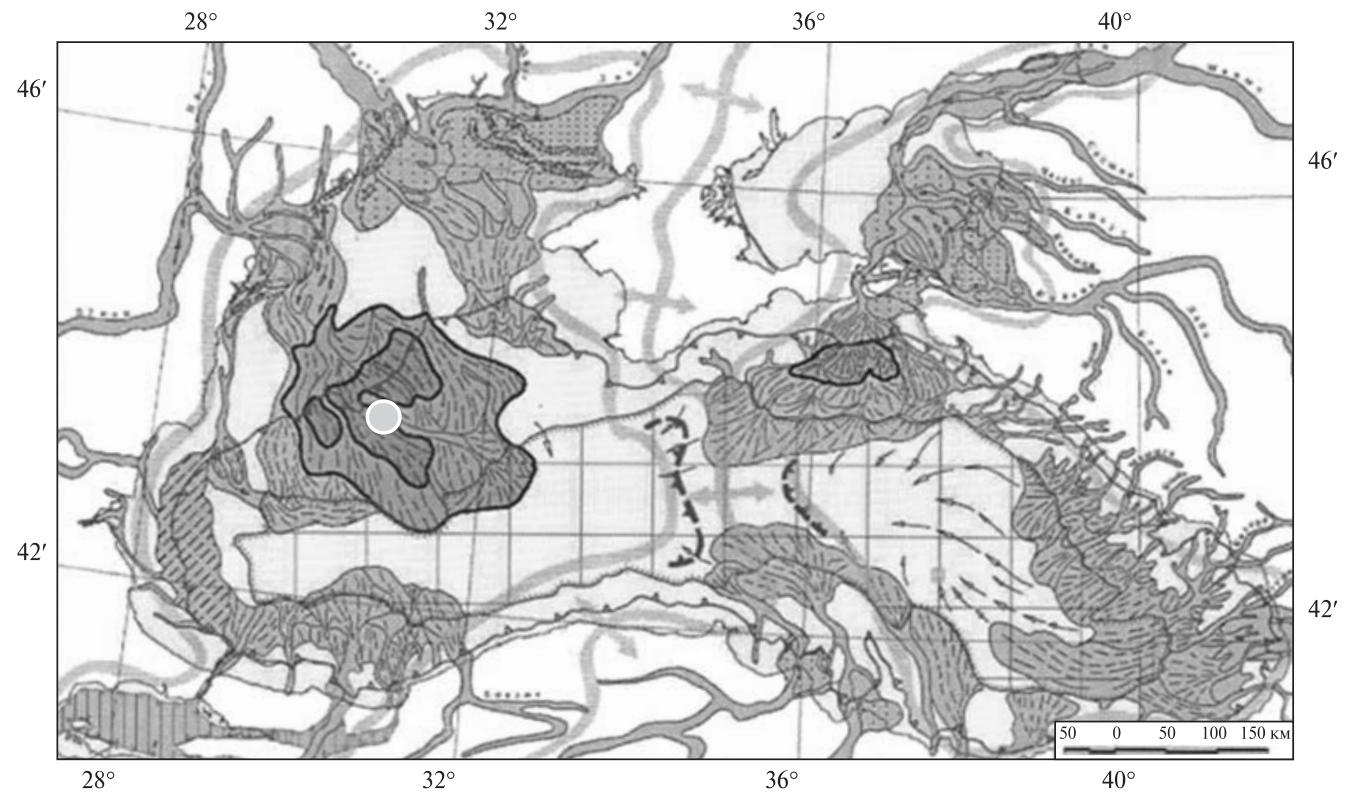

Puc. 2. Местоположение газового месторождения Домино-1 (по Леончик и др., 2015) 


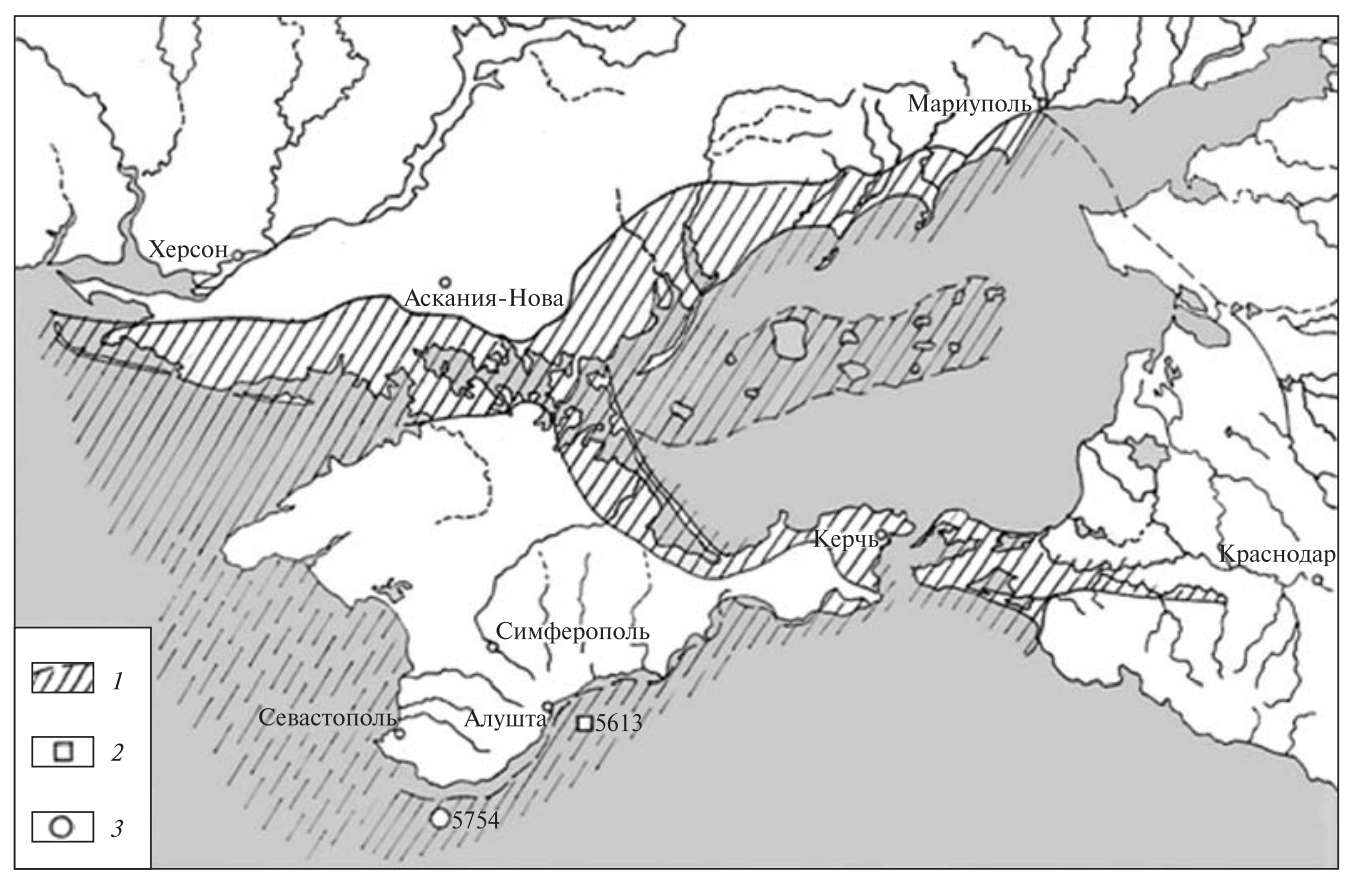

Puc. 3. Азово-Черноморская железорудная провинция: 1 - площадь распространения киммерийских отложений и предполагаемые ее границы; $2-$ киммерийскими отложения, поднятые в 57-м рейсе НИС «Профессор Водяницкий»; 3 - киммерийская фауна, извлеченная при драгировании в том же рейсе

зевых вулканов. Одним из средоточий газогидратов является континентальный склон, особенно погруженные палеодельты. В литературе описаны залежи газогидратов в палеорусле Дуная, залежь газогидратов в палеодельте Днепра (Каланчака), в Туапсинском прогибе. Наши основные находки газогидратов при геологических исследованиях связаны с грязевыми вулканами. Учитывая реальную политическую ситуацию, необходимо, по нашему мнению, сосредоточиться на изучении и освоении залежей газогидратов возле грязевых вулканов. Это месторождения типа норвежского вулкана Хаакон Мосби, вокруг которого газогидратная залежь образует огромное кольцо [14].

Еще один важный вид минерального сырья - железные руды, приуроченные к неогеновым (киммерийским) отложениям. Обширная Азово-Черноморская железорудная провинция охватывает Керченский полуостров, часть северо-западного Кавказа, Присивашье, северное Приазовье (рис. 3). Морскими работами удалось проследить киммерийские отложения на южном морском склоне Крыма и на запад от Крыма, где рудоносные киммерийские отложения фациально выклиниваются и в направлении на запад сменяются песчаными дакийскими отложениями. Суммарно запасы железных руд на суше оцениваются в 8-9 млрд т, причем богатые руды на Керченском п-ове составляют порядка 2 млрд т и длительное время разрабатывались Камыш-Бурунским железорудным комбинатом в объеме до 6-7 млн т ежегодно. Геологически для поисков наибольший интерес представляет северо-западная часть Азовского моря. Весь северо-западный склон Азовского моря рудоносен. Структурно впадина между склоном Украинского (Приазовского) массива и Азовским валом в своей западной периклинальной части предс- 
Puc. 4. Железорудные отложения в акватории Керченского пролива: 1 - антиклинальные структуры и оси, 2 синклинальные структуры и оси, 3 - площади развития киммерийских отложений, 4 - линии тектонических нарушений

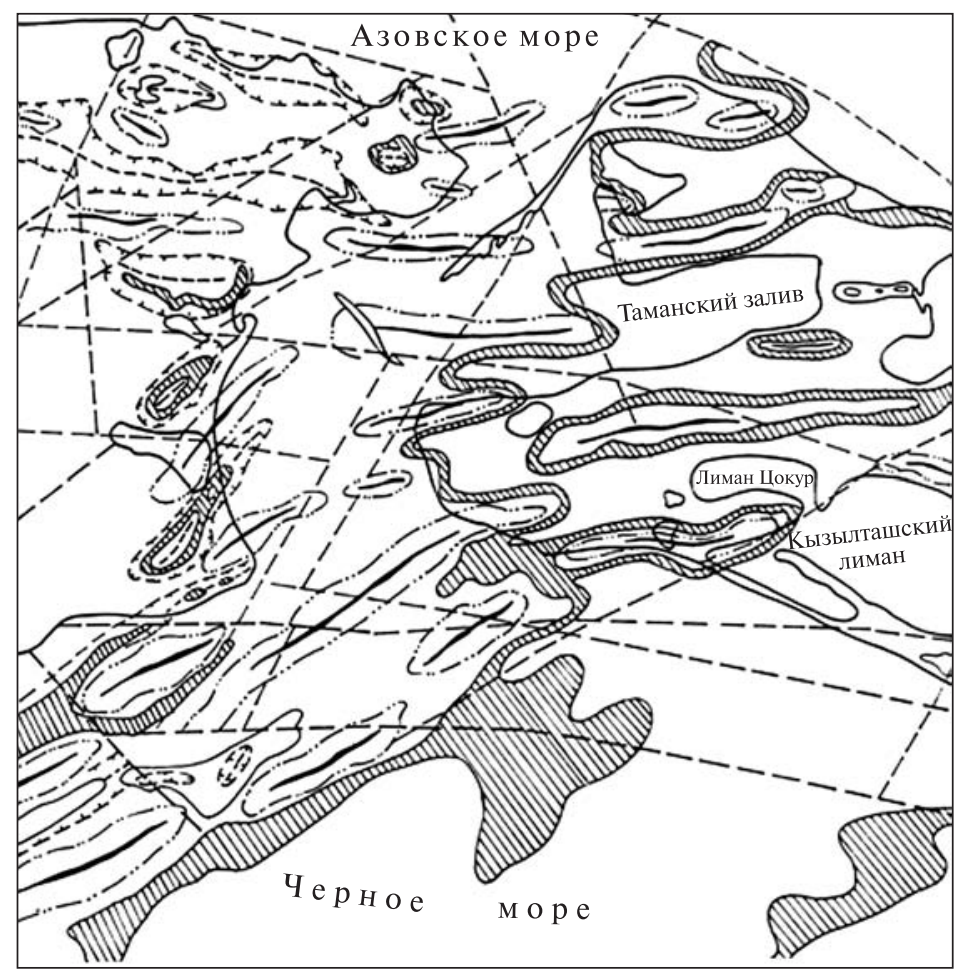

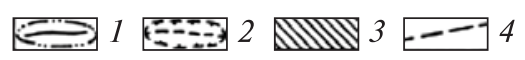

тавляет обширную рудоносную площадь, сложенную предположительно железистыми песчаниками и оолитовыми рудами.

Этот район моря еще недостаточно изучен. К сожалению, пробуренная здесь на Электроразведочном поднятии скважина была пройдена без керна. Тем не менее, зеленый цвет шлама залежи перетертых табачных руд был зафиксирован. Здесь может существовать новый аналог Керченского бассейна.

Перспективны, в частности, участки акватории Черного моря к югу от Керченского и Таманского п-овов (рис. 4). Судя по данным сейсмики, на северном склоне Таманского полуострова в районе между грязевыми вулканами Пекло Азовское (мыс Каменный) и банкой Казбек прослеживается предположительно структура типа вдавленной синклинали с киммерийскими отложениями большой мощности (рис. 5).

Несколько лет тому назад, за год-два перед Сочинской олимпиадой, возник бум потребления морских песков. Оказывается, арабские шейхи, успешно построившие в Саудовской Аравии несколько песчаных островов в море, решили перенести свой опыт на Сочи и построить остров для олимпийской застройки. Скажем прямо, идея эта была ошибочна и в условиях узкого кавказского шельфа, изрезанного каньонами, еретическая. Но все же возник запрос на крупные объемы песков - до 100 млн м³. Оказалось, в условиях Азово-Черноморского бассейна серьезные запасы песков есть только на северо-западе Черного моря. Общие запасы северо-запада Черного моря оцениваются в 11,5 млрд м ${ }^{3}$. Проведенная ревизия запасов песков показала большие перспективы северо-запада Черного моря. 


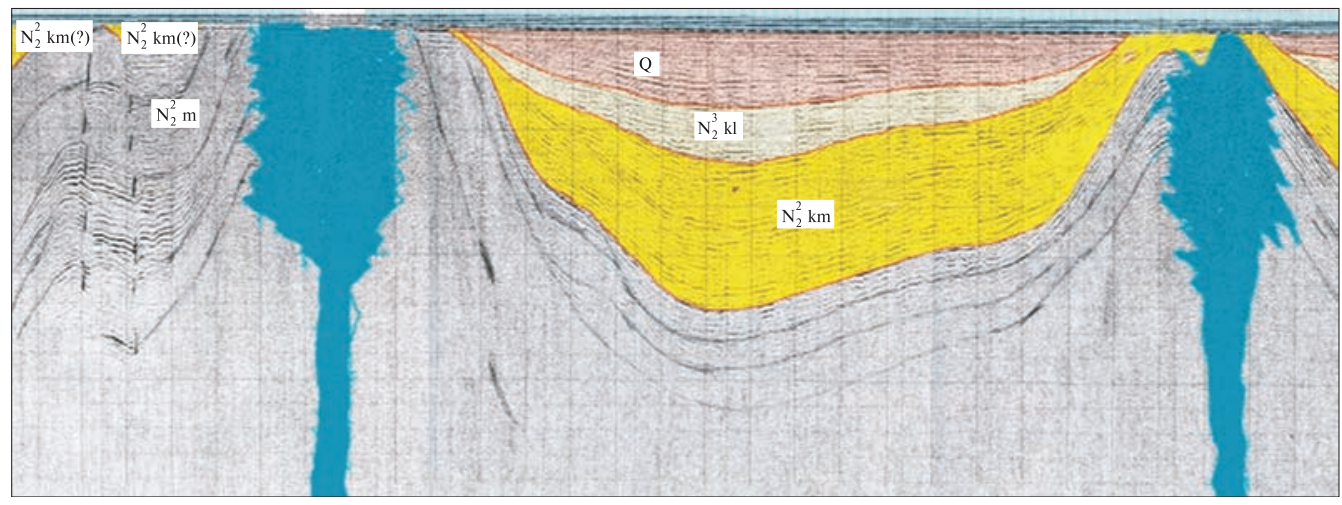

Puc. 5. Предположительная структура типа вдавленной синклинали на северном склоне Таманского полуострова с киммерийскими отложениями большой мощности

Здесь находится целый ряд месторождений, уже найденных и разведанных. Это Одесская банка, где можно ожидать до 10 млрд м³ песков, Бакальская банка, Сергеевское, Терновское-2 и Терновское-38, Алибейское месторождения близ устья Днестра и многие другие (рис. 6). Но на данный момент от идеи острова отказались.

Возникла новая задача - строительство кругочерноморской трассы. Пока она тоже не реализована. Была еще идея строительства большого порта в северо-западном Крыму для КНР. Сам факт наличия серьезной базы стройматериалов на северо-западе моря будоражит воображение и привлекает внимание строителей. Добавлю, что эта база может быть расширена и увеличена при условии серьезных разведочных работ. Многочисленные палеоаллювиальные ложа Днепра, Днестра, Южного Буга и других рек - серьезная перспектива поисков стройматериалов.

Сельское хозяйство Украины испытывает существенную нехватку минеральных удобрений. В 2006 г. потребности оценивались в 1,5 млн т пятиокиси фосфора, но они не удовлетворялись полностью. При этом происходит деградация наших черноземов, теряющих постепенно свою плодородность [4].

Возникает вопрос о дополнительных источниках подкормки. В этой связи вспоминаются черноморские сапропели. Сапропель - гнилой ил в переводе с греческого. Впервые термин употреблен в 1901 г. для отложений, обогащенных органикой и имеющих запах сероводорода. Широко использован в литературе по Черному морю А.Д. Архангельским и Н.М. Страховым. Практика использования сапропелей в Украине уже существует. В озерах Волыни выявлено 74,5 млн т болотных сапропелей [12]. Максимум добычи в 1992 г. составил 160 тыс т, затем добыча резко упала.

Между тем, сапропели изучались уже давно. В СССР существовал до середины 30-х годов специальный комитет по сапропелю, установивший широкий спектр использования этого сырья.

Морские сапропели по качественным характеристикам превосходят свои болотные аналоги. Практически каждый исследователь донных осадков Черного моря описывал сапропели. Более или менее детально ими занимались еще А.Д. Архангельский и Н.М. Страхов, П.Н. Куприн, Ф.А. Щербаков, К.М. Шимкус, а в конце XX столетия по проектам НАМИТа (Национальное агентство морских исследований и технологий Украины) - Е.Ф. Шнюков, С.А. Клещенко, Т.С. Куковская, А.П. Зиборов и другие. 
Обычно сапропели фиксируются на глубинах более 400-500 м. Мощность всей толщи обогащенных сапропелевых осадков изменяется в различных районах моря от 0,35 до 2 м. Распределение сапропелей обусловлено рельефом дна. Максимальные мощности обусловлены процессами оползания осадков на крутых склонах. По своему химизму сапропель своеобразен. Химизм и литология сапропеля изучены во многих работах наших, болгарских, румынских специалистов. Содержание ведущего элемента $\mathrm{C}_{\text {орг }}$ в среднем $10,23 \%, \mathrm{P}_{2} \mathrm{O}_{5}$ - от 0,2 до 0,3\%.

Сотрудники Причерноморской экспедиции установили несколько площадей с содержаниями в сапропелях 0,02 \% Мо (115 кларков концентрации). Максимальные содержания - 0,03-0,0329\%.

Применение сапропелей - удобрение, медицина, строительное дело и другие.

Многолетние исследования, финансируемые НАМИТом, показали, что сапропель на треть увеличивает прирост урожаев. Изучены разные почвы, разные виды растений. Такие же исследования проведены в Болгарии - с теми же положительными результатами. Необходимо ставить вопрос об использовании черноморских сапропелей. Интерес к этому виду сырья проявляли в Европе, Саудовской Аравии. Видимо, мы плохо рекламируем наши возможности.

Еще один важный вид полезных ископаемых, о котором незаслуженно забывают в последние годы - пресная вода. Субмаринные источники известны во многих районах Мирового океана, в частности, в Средиземном море. В некоторых районах они вскрыты буровыми скважинами в море (Флорида, Австралия).

В Азово-Черноморском регионе известны субмаринные выходы пресных вод трех типов - артезианская разгрузка, подрусловой сток, субмаринные выходы из

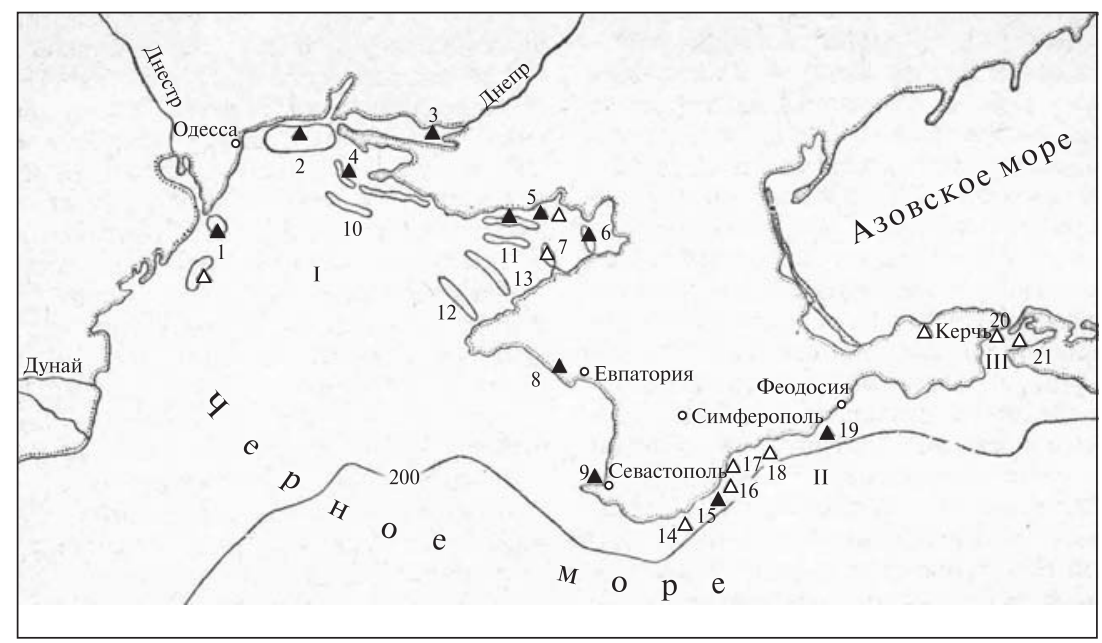

Puc. 6. Месторождения песков в акватории Черного моря: I - северо-западный район; II шельф Горного Крыма; III - Керченский пролив и прилегающий шельф Черного моря. Мecmoрождения: 1 - Терновская и Алибейская банки, 2 - Одесская банка, 3 - Днепровско-Бугский лиман, 4 - Тендровский залив, 5 - Джарылгачский залив, 6 - Чурюмская банка, 7 - Бакальская банка, 8 - Донузлавский лиман, 9 - район Севастополя; погребенные аккумулятивные формы, косы: 10 - Древнетендровская, 11 - Древнеджарылгачская; пересипи: 12 - Древнетарханкутская, 13 - Древнеярылгачская; аккумулятивные тела шельфа Горного Крыма: 14 - между Ласточкиным Гнездом и Симеизом, 15 - в Ялтинской бухте, 16 - между мысом Никита и Гурзуфом, 17 - между Аюдагом и с. Рыбачьим, 18 - между Алуштой и с. Морским; 19 - устье р. Отузки; III - аккумулятивные тела в акватории Керченского пролива и прилегающем шельфе Черного моря: 20 - Церковная банка, 21 - коса Русанова 


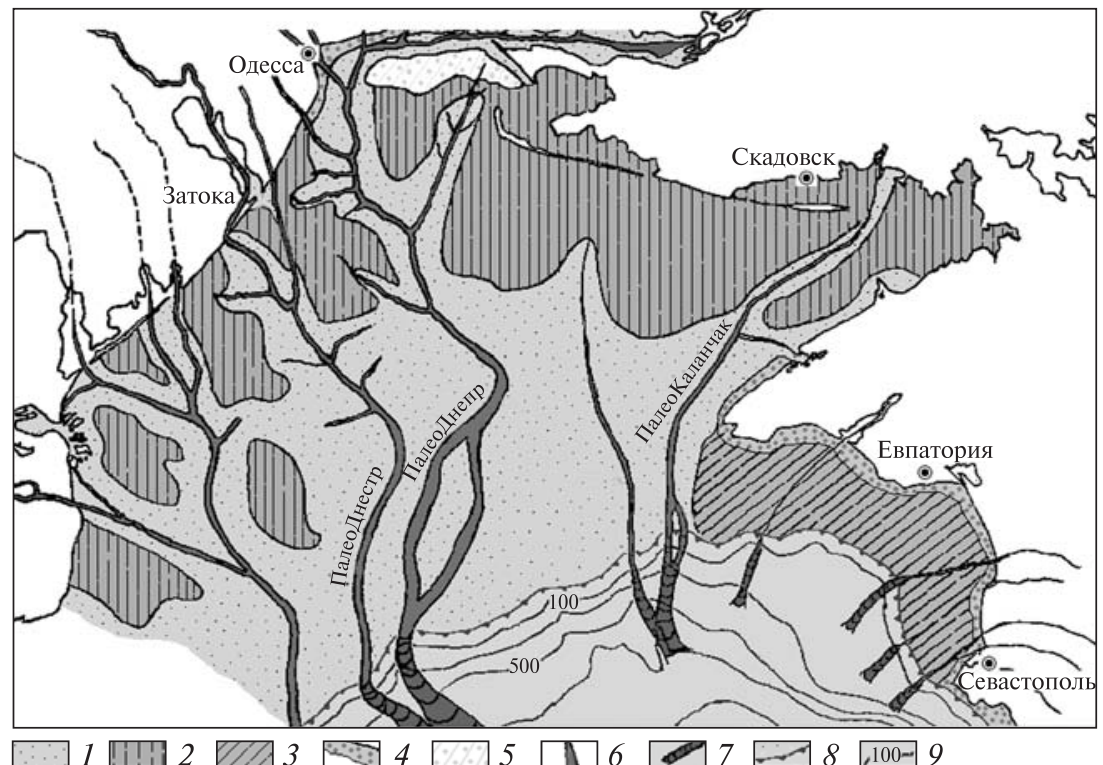

Puc. 7. Палеорусла рек на шельфе Черного моря: 1 - аллювиальные равнины, 2 - пологие возвышенности, сложенные позднеплейстоценовыми морскими и континентальными отложениями; 3 - пологонаклоненные предгорные возвышенности; 4 - обрывистые берега и прибрежные участки морского дна, сложенные коренными породами; 5 - крупные реликтовые аккумулятивные песчаные тела; 6 - русла палеорек; 7 - подводные конуса выноса; 8 береговая линия моря в период максимальной верхнеплиоценовой регрессии, 9 - изобаты

карбонатных карстовых массивов. В настоящее время, пожалуй, особый интерес вызывает подрусловой сток рек. На украинском шельфе - особо благоприятные условия для поисков субмаринных источников подруслового стока. На северо-западном шельфе прослеживаются палеорусла многих рек - Днепр, Днестр, Южный Буг, более мелких. В Азовском море - палеорусло Дона (рис. 7).

Хроническая нехватка воды на юге Украины и в Крыму известна издавна. Были серьезные проекты преодоления этой проблемы. В восьмидесятые годы прошлого столетия был выдвинут широко известный в то время проект переброски части дунайских вод в бассейн Днепра - примерно одного кубокилометра. Предполагалось опреснить лиман Сасык, из него каналом перебросить воду в бассейн Днепра лотками поверх одесских лиманов. Но опреснить Сасык не удалось, и под натиском защитников природы проект рухнул. Н.А. Гаркушу, министра водного хозяйства Украины и одного из инициаторов проекта, сместили. Однако проблема осталась. Воды югу нашей страны летом остро не хватает. Между тем, можно ожидать геологического решения этой проблемы.

Каждая река - сложное двухэтажное сооружение природы. То, что мы называем рекой и учитываем ее вынос - это поверхностный сток. Существует, однако, еще один сток - подрусловой, который происходит в аллювиальном ложе реки. Этот подрусловой сток во многих случаях недостаточно изучен и, по литературным данным, составляет примерно до трети руслового. Можно представить массы воды, которые бесполезно уходят в морские глубины, если учесть, что только Днепр выносит примерно 53,5 км³.

Палеоречной сети на северо-западе Черного моря был посвящен один из рейсов - 5-й рейс НИС «Киев». Во время рейса изучался подрусловой сток в палео- 


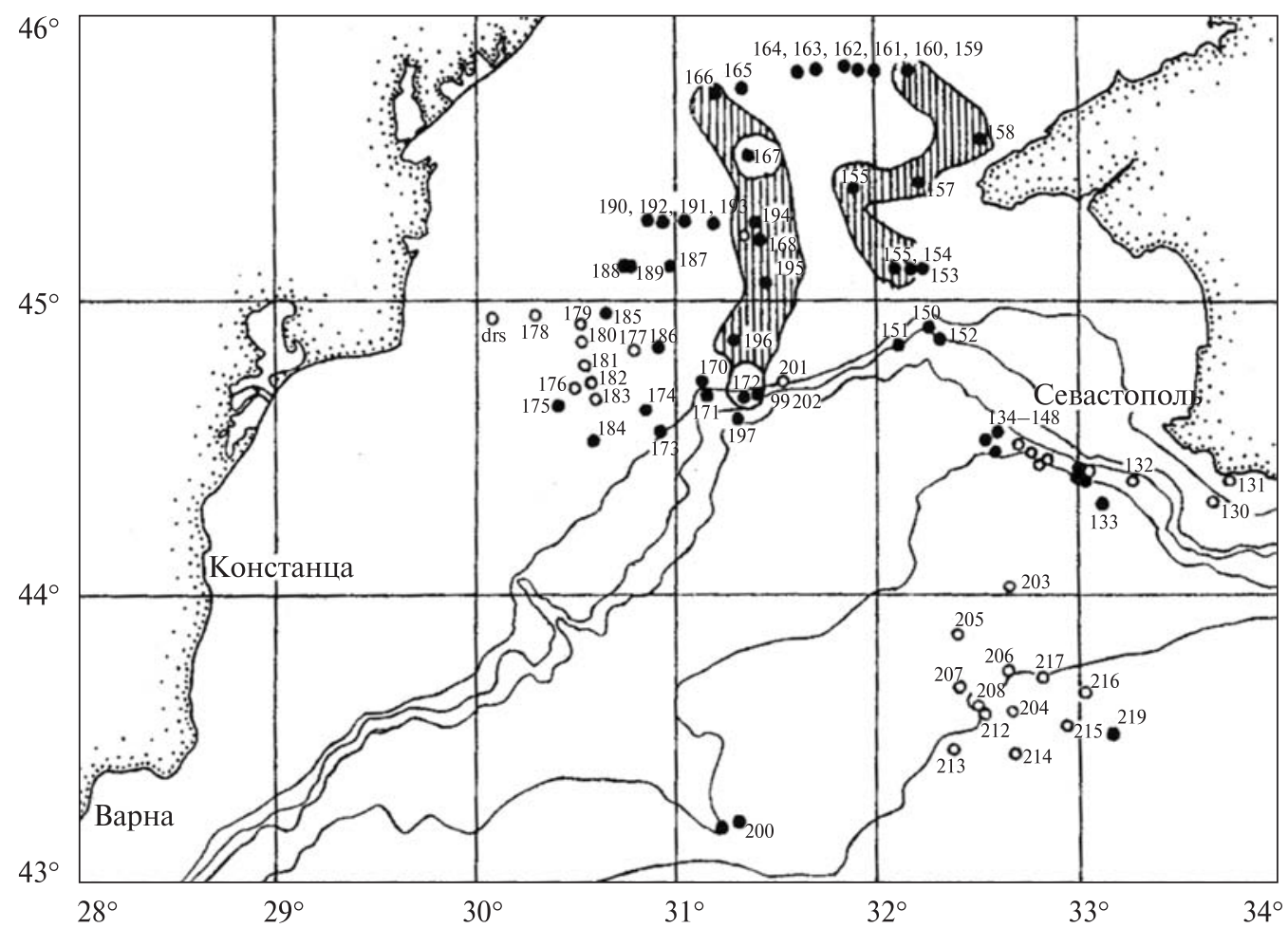

Puc. 8 . Современная разгрузка пресной воды одного из палеорусел
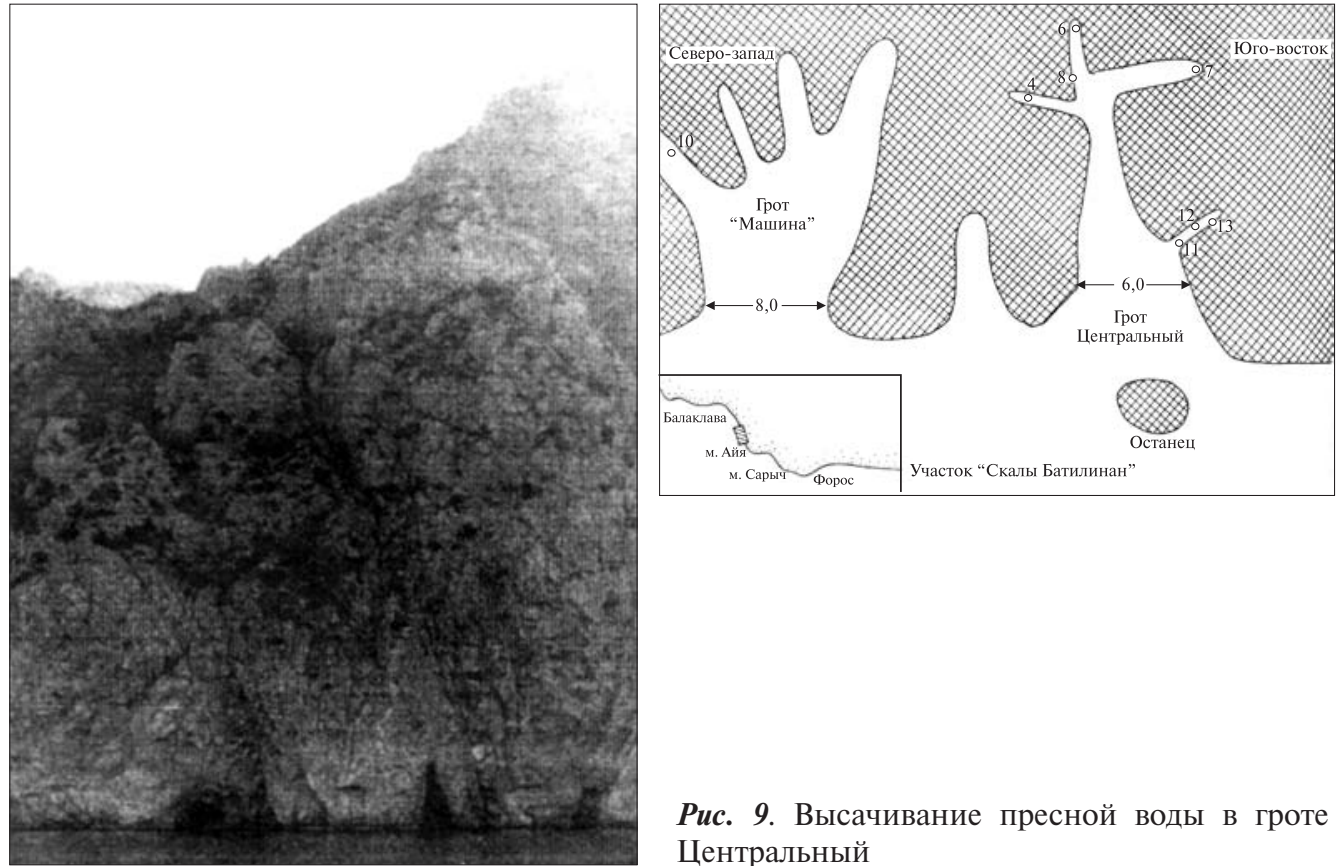

Puc. 9. Высачивание пресной воды в гроте Центральный 


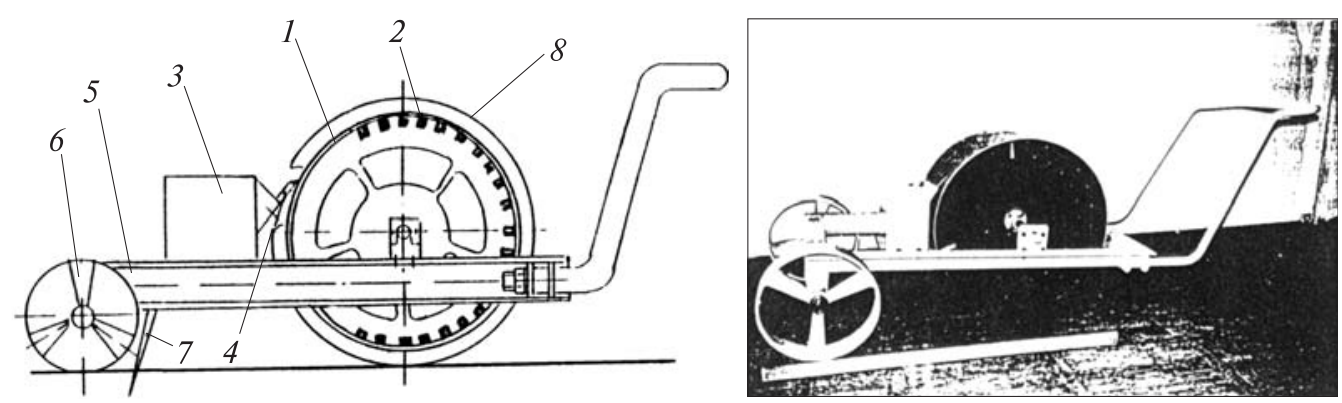

Puc. 10. Горные «машины сбора урожая» для добычи ильменит-цирконовых россыпей Приазовья: 1 - барабан; 2 - магниты; 3 - бункер-накопитель; 4 - скребок; 5 - несущая рама; 6 - ось барабана; 7 - разрыхлитель; 8 - обода, регулирующие давление на поверхности песка

долинах. В качестве индикаторов возможной разгрузки пресных вод были выбраны концентрации кремния и солености как наиболее контрастные показатели для речных и морских вод. Удалось установить, что максимальные концентрации кремния (700-2070 мкг/л) приурочены к долинам палеорек. В междуречьях кремний содержался в меньших количествах - не более 600 мкг/л. По материалам рейса удалось проследить современную разгрузку пресной воды одного из палеорусел (рис. 8). Все эти работы были организованы ОМГОР НАН Украины (Е.Ф. Шнюков, С.А. Клещенко) и Севастопольским отделением Всесоюзного океанографического института (В.И. Губанов, Н.И. Субботин). К сожалению, дальнейшего развития эти работы не получили. Необходимо морское бурение на воду. В Азовском море наша скважина № 17 (в пятидесяти километрах севернее бухты Булганак) попала в одно из палеорусел Дона, прошла два десятка метров по аллювиальным пескам. В результате бурения самотеком была получена пресная вода.

Еще один тип разгрузки - субмаринные источники карбонатных закарстованных массивов. Они широко распространены на Кавказе, в Крыму, в Турции. Так, например А.Б. Климчук [6] отмечает наличие вытекающих из кавказского массива Арабика выходов пресных вод на берегу Черного моря и в море.

Крым в этом отношении типичный объект исследования. Установлено, что субмаринные источники проявлены на южном берегу Крыма от Балаклавы до Феодосии. Несколько субмаринных источников издавна известны на мысе Айя. В западной части отвесной гряды высотой до 150-300 м над уровнем моря - серия подводных и надводных гротов, проникающих в глубь скал на 20 и больше метров и здесь, в частности, в гроте Центральный высачиваются источники пресной воды дебитом до 100-150 литров/мин (рис. 8, 9).

Отделение морской геологии проводило несколько рейсов с целью изучения роли каньонов в субмаринной разгрузке. Из сотни крымских каньонов изучены Балаклавский, Батилиманский, Сарычский, Алупкинский, Ялтинский, Гурзуфский, Саудагский, Плака, Кастель, Алуштинский, Малореченский, Судакский каньоны. Склоны каньонов сложены породами мезозоя и кайнозоя. Работы включали промер и сейсмоакустическое профилирование, было изучено около 300 проб воды. В каньонах обнаружено высачивание пресных вод. Соленость воды у дна каньонов достигала 11, 13, 17\%о при 21-22 \%о на поверхности воды. 
B.X. Геворкьян во время спусков на подводном аппарате КЧФ наблюдал в одном из каньонов на глубине 600 м небольшой очаг не сероводородной воды с активным рыбным населением на континентальном склоне.

Большой интерес представляет изучение прибрежных морских россыпей и в целом древних береговых линий. В Азово-Черноморском бассейне известны ильменит-циркон-монацитовые и магнетитовые россыпи. Первые вытянуты на 111 км вдоль северного берега Азовского моря. Другие встречены в Болгарии (протяженность до 50 км), в Грузии (до 50 км), в Западном Крыму. Это современные россыпи, мощности их не велики, концентрации не высоки. Вещественный состав россыпей изучается в наши дни современными методами и при этом обнаружено много новых минералов.

В частности, в россыпях найдено много самородных минералов. Добыча их в современных условиях нерентабельна, ибо приведет к отрицательным экологическим последствиям.

По нашему мнению, добыча ильменит-цирконовых россыпей Приазовья возможна лишь в условиях применения нового типа оборудования, принципиально нового. Мы совместно с А.П. Зиборовым получили патент на новый тип горной машины - «машины сбора урожая» (рис. 10). Оборудованный электромагнитом, аппарат собирает с поверхности пляжа электромагнитные частицы (титаномагнетит, ильменит и циркон электромагнитны), не нарушая среду. Море, как гигант-

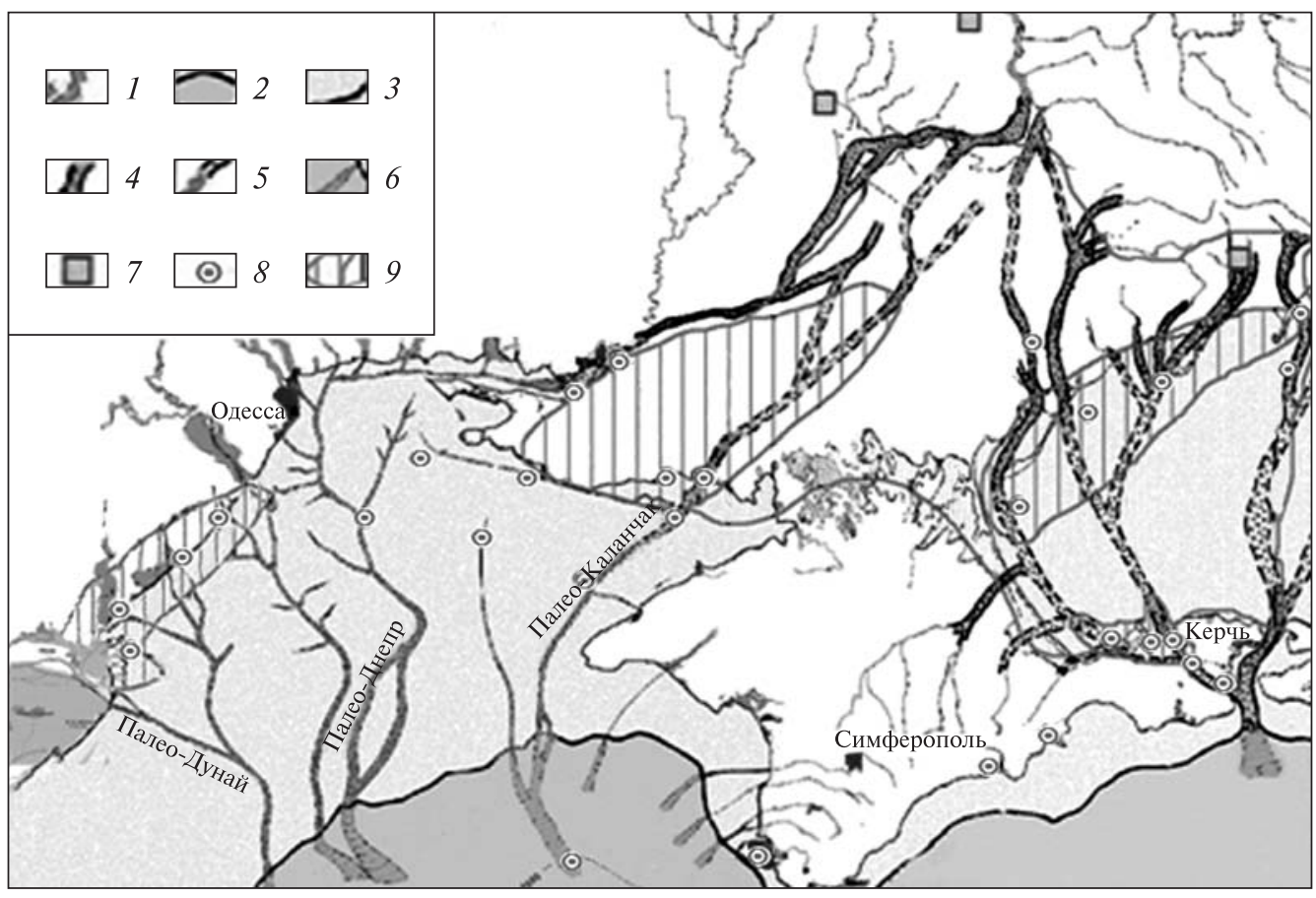

Puc. 11. Обобщенная карта находок золота: 1 - современные лиманы и озера; 2 - береговая линия моря в период максимальной верхнеплиоценовой регрессии; 3 - осушившаяся шельфовая зона; 4 - долины палеорек, установленные в результате буровых работ; 5 - предполагаемые долины палеорек; 6 - подводные конусы выноса палеорек; 7 - золоторудные месторождения на УЩ; 8 - находки и рудопроявления тонкого золота; 9 - участки, намеченные для поисков проявлений тонкого золота 
ская обогатительная машина, ежегодно пополняет пляжи минералами. Объезжая пляжи, можно ежегодно собирать значительное количество рудных минералов, не нарушая пляжную среду.

Интерес представляют полезные ископаемые россыпей, скрытые современным морем. Уровень Азовского моря в четвертичное время неоднократно менялся, оставляя береговые линии под водой, а вместе с ними - захороненные россыпи. Минералогический состав россыпей позволяет проводить их поиски в море. В составе россыпей всегда присутствуют титано-магнетит и монацит. Тщательное геофизическое изучение береговых россыпей позволит составить своего рода портрет россыпей, технический паспорт. Поиски такого рода прибрежных участков моря позволяют выявить магнитные и радиометрические линейные аномалии захороненных россыпей. Еще более результативным могут быть поиски магнетитовых россыпей у берегов Болгарии и Грузии.

К сожалению, наличие радиоактивного монацита усложняет освоение россыпей. В наши дни потребности промышленности в монаците ограничены, потребности фактически нет.

Еще один заслуживающий внимания элемент в россыпях - золото, точнее тонкое золото.

Черное море было открыто древними греками и всем античным миром в поисках золота. Аргонавты в ХІІІ веке до нашей эры плыли к берегам Кавказа за золотым руном. В древности на Кавказе для добычи золота поперек водного потока клали баранью шкуру, в которой в случае золотоносности потока накапливались золотинки, давая «золотое руно». Но искали золото по берегам бассейна. Во второй половине XX века золото в прибрежно-морских россыпях Черного моря в виде единичных зерен было обнаружено у берегов Крыма [2, 8, 16]. Лишь после признания роли тонкого золота и создания установки для его изучения (у нас В.Т. Кардаш) работы на золото получили существенное развитие. На рис 11 наводится обобщенная карта находок золота прошлого столетия.

Восточная часть севера Черного моря изучалась геологами ОМГОР и Крымской экспедиции (Е.Ф. Шнюков, Н.А. Маслаков, Ю.И. Иноземцев, О.Г. Сиденко, В.Т. Кардаш, А.В. Вишневецкий, И.В. Гаврилюк и др.), северо-западная часть моря - геологами Одесского университета и Причерноморской экспедиции (В.П. Резник, И.А. Мудров, Н.О. Федорончук, И.О. Сучков и др.). Итоги исследований таковы: на Керченском полуострове открыто несколько рудопроявлений и два небольших месторождения, изучено рудопроявление у г. Судак, коренное проявление золота на Гераклейском полуострове, геохимически выявлено золото в Ломоносовском подводном массиве, в подводной долине палео-Каланчака. Найдено 6 аномальных по содержанию пятен золота в Азовском море. Специалистами Одесского университета и Причерноморской экспедиции выявлено пять участков высокого содержания золота в северо-западной части моря: Палеоднестровский, Жебриянская бухта, Сухой лиман, Праднепровский, Тендра. Прогнозные запасы всех пяти участков оцениваются в 133,7 т, средние содержания от 212 до 0,692 г/т [9].

Плодотворной научной идеей оказалось предположение о важной роли в выносе золота с УЩ палео-Днепра, а также Днестра.

Сделано много и перспективы есть. К сожалению, все эти работы фактически заброшены. Часть, по понятным причинам, из-за аннексии Крыма. Но в основном из-за упадка геологии. 
Хочется выразить надежду на продолжение этих работ в ближайшем будущем. Тем более, в литературе утверждается — «XXI - век тонкого золота».

Работами ОМГОР НАН Украины удалось открыть и изучить меловой Ломоносовский подводный массив к юго-западу от Севастополя [22, 23] Найдены кристаллические породы возрастом 350 млн лет на Форосском выступе, на северо-западном шельфе. Вероятны выходы кристаллических пород в Алуштинском полуцирке в море, на юго-востоке Черного моря. Задачи изучения магматизма Черного моря в полный рост встанут перед исследователями в ближайшем будущем.

Еще предстоит оценить значение черноморских конкреций, черноморского жемчуга.

В будущем, я надеюсь в далеком будущем, нам, вероятно, все же придется вернуться к вопросу о сероводородном заражении Черного моря, особенно если будет зафиксирован подъем его уровня. В 1992 г. Международное совещание специалистов в Стамбуле как будто бы констатировало более или менее постоянный уровень сероводородного заражения, хотя голоса специалистов, отмечавших его подъем, звучали довольно громко. В последние годы Советской власти в Комитете по науке и технике СССР даже рассматривали химерический экологический проект Р. Ахмедова с целью снижения уровня сероводорода и добычи серы из вод Черного моря. Предполагалось откачивать глубинную черноморскую воду, содержащую до 8 мл/л сероводорода, извлекать из нее сероводород и закачивать в водную толщу. Энергию для этого должны были давать два десятка атомных или тепловых станций по периферии моря. Проект был отклонен, строительство в сейсмически опасных зонах и угроза появления кислотных дождей оказались серьезными аргументами против. Однако исходные проблемы остались.

Выявленный минерально-сырьевой потенциал Черного моря весьма серьезен. Тем не менее, надо иметь в виду, что фактически это потенциал только северной половины бассейна. Вся турецкая (а это южная половина) часть акватории практически мало изучена. Между тем, в юго-восточном углу Черного моря большая подводная горная страна; в юго-западном углу расположен снабжающий всю Турцию Эрегли-Зангулдакский угольный бассейн, где часть угольных пластов $(1 / 3)$ находится под водами моря и разрабатывается подводными горными работами. Запасы бассейна 1,2 млрд т.

На северо-западе турецкого берега мы наблюдали выходы пресных вод в подводных каньонах континентального склона. Здесь вероятны прибрежно-морские россыпи и многое другое.

Для того, чтобы решить сложные прикладные задачи освоения минеральносырьевого комплекса Черного моря нужны серьезные фундаментальные исследования хотя бы в двух направлениях - палеогеографические, с выявлением геологической истории Азово-Черноморского бассейна и связанные с ними исследования истории и палеогеографии речной сети Азово-Черноморского бассейна. Эти исследования обеспечат научную базу для поисков песчаных толщ, пресной воды, россыпей, всего комплекса минеральных ресурсов.

Украина - морская держава. В будущем нам надлежит не ограничиваться работами в Черном море. Перед нами стоят задачи изучения Средиземного моря, в частности его грязевых вулканов, Мирового океана и его металлогении - железомарганцевых конкреций, рудных илов и других богатств [20, 21]. Опыт исследований прошлых лет позволяет надеяться и на успешный выход в Мировой океан [18]. 
Как заключение, отмечу, что многое из приведенного дискуссионно. Это гипотезы, идеи. Я хотел бы только подчеркнуть огромный объем работы, стоящей перед морскими геологами Украины и всего черноморского региона. Задачи их развития, проверки велики, но и приз - минерально-сырьевые ресурсы Черного моря - огромен. Его освоение позволит ускорить промышленное развитие страны, развитие сельского хозяйства, улучшать жизнь нашего народа.

\section{Заключение}

Рассмотрены основные направления исследований и освоении минерально-сырьевого потенциала Азово-Черноморского бассейна (нефтегазоносность, газ, газогидраты метана, железные руды, строительные пески, сапропели, пресная вода, ильменит-циркониевые и магнетитовые прибрежно-морские россыпи, тонкое золото и др.). Отмечаются перспективы их освоения и необходимость расширения морских исследований в Мировом океане.

\section{СПИСОК ЛИТЕРАТУРЫ}

1. Барковская М.Г. Некоторые закономерности образования в водоемах промышленных концентраций тяжелых металлов. Геология рудных месторождений. 1963. № 1. С. 50-64.

2. Геродот. История: в 9 кн. М.: Наука, 1972. 600 с.

3. Грязевые вулканы Черного моря: каталог. Нац. акад. наук Украины, ГНУ «Отд-ние мор. геологии и осадоч. рудообразования»; авт.-сост.: Шнюков Е.Ф., Ступина Л.В., Рыбак Е.Н.; под ред. Е.Ф. Шнюкова. Киев: Логос, 2015. 255 с.

4. Гурський Д.С., Єсипчук К.Ю., Калінін В.І. та ін. Металічні і неметалічні корисні копалини України. НАН України, Держ. геолог. служба України. К.: Центр Європи, 2006. Т. 1: Металічні корисні копалини. наук. ред. М.П. Щербак, О.Б. Бобров. 2006. 739 с.

5. Егоров В.Н., Артемов Ю.Г., Гулин С.Б. Метановые сипы в Черном море. Средообразующая и экологическая роль. Севастополь: Экса-гидрофизика, 2011. 404 с.

6. Климчук О.Б. Розвиток найглибших карстових систем і субмаринне розвантаження масиву Арабіка (Західний Кавказ): роль пізньоміоценової регресії Східного Паратетісу. Геол. $i$ кор. копалини Світового океану. 2018. № 1 (51). С. 58-82.

7. Никонов А.А. Крымские землетрясения 1927 года. Неизвестные явления на море. Природa. 2002. № 9. C. 13-20.

8. Полканов Ю.А., Яловенко И.П. О находках золота в прибрежно-морских и лиманных песках северо-западного побережья Черного моря. ДАН СССР. 1970. Т. 191. № 4. С. 905-908.

9. Резник В.П. Некоторые проблемы морского тонкого золота (северо-западный шельф Черного моря). Геол. и полезн. ископ. Черного моря. Киев: ОМГОР НАНУ, 1999. С. 147-151.

10. Русаков О.М., Кутас Р.И. Фата-моргана биогенной доктрины углеводородов в Черном море. Геофиз. журнал. 2014. № 2. С. 2-17.

11. Сенин Б.В., Леончик М.И., Хортов А.В. и др. Новые данные о глубинной структуре Черноморской впадины. Актуальные проблемы развития ТЭК регионов России и пути их решения: Сб. трудов науч. конф. Геленджик: ГНЦ «Южноморгеология», 2013. С. 125-128.

12. Шевчук М.И. Сапропелі України: запаси, якість та перспективи використання. Луцьк: Надстир'я, 1996. 384 с.

13. Шнюков Е.Ф., Кардаш В.Т. Проявления золота в донных отложениях акватории Черного моря. Геол. журн. 1994. № 3. С. 127-128.

14. Шнюков Е.Ф., Коболев В.П. Грязевулканические залежи газогидратов метана в Черном море. Геол. и полезн. ископ. Мирового океана. 2018. № 1. С. 5-34.

15. Шнюков Е.Ф., Маслаков Н.А. Золотоносность осадочных отложений Керченского полуострова. 3б. наук, праць Ін-ту геохімії навколишнього середовища. 2002. Вип. 5/6. С. 7684. 
16. Шнюков Е.Ф., Маслаков Н.А., Сиденко О.Г. Золотоносность Крыма и прилегающей акватории Азово-Черноморского бассейна. Геол. и полезн. ископ. Черного моря. Киев: ОМГОР НАН Украины, 1999. С. 189-193.

17. Шнюков Е.Ф., Маслаков Н.А., Скорик А.Н. и др. О золотоносности песчаных отложений Керченского полуострова. Геол. и полезн. ископ. Мирового океана. 2008. № 2. С. 53-67.

18. Шнюков Е.Ф., Орловский Г.Н., Клещенко С.А. и др. Железомарганцевые конкреции Индийского океана. К.: ОМГОР, 2001. 329 с.

19. Шнюков Е.Ф., Сиденко О.Г. Строительные пески на черноморском шельфе УССР. Тектоніка і стратиграфія. 1979. Вип. 17. С. 81-96.

20. Шнюков Е.Ф., Старостенко В.И., Плошко В.В. и др. Геология и металлогения тропической Атлантики. К.: Наук, думка, 1989. 189 с.

21. Шнюков Е.Ф., Старостенко В.И, Щербаков И.Б. и др. Геология и металлогения северной и экваториальной частей Индийского океана. Киев: Наук, думка, 1984. 168 с.

22. Шнюков Е.Ф., Щербаков И.Б., Шнюкова Е.Е. Палеоостровная дуга Черного моря. К.: Чернобыльинформ, 1992. 287 с.

23. Шнюкова Е.Е. Магматизм зоны сочленения Западно-Черноморской впадины, горного Крыма и Скифской плиты. Киев: Наукова думка, 2016. 234 с.

Статья поступила 03.03.2019

\section{Є.Ф. Шнюков}

\section{ЧОРНЕ МОРЕ: МАЙБУТНЕ МІНЕРАЛЬНО-СИРОВИННОЇ БАЗИ}

У статті розглядаються можливі шляхи геологічного вивчення та освоєння мінерально-сировинного комплексу Чорного моря, зокрема, енергетичного комплексу, оолітових залізних руд, будматеріалів, мінеральних добрив, прісної води, титано і магнетитових розсипів, тонкого золота. Підкреслюється необхідність вивчення і освоєння газогідратів. Відзначено важливість фундаментальних досліджень для прикладної геології, особливо вивчення кристалічних порід Чорного моря для розуміння його геологічної історії та будови.

Ключові слова: Чорне море, мінерально-сировинна база, сапропелі, газогідрати метану, прибережно-морські розсипи, тонке золото.

\section{Ye.F. Shnyukov}

\section{BLACK SEA: THE FUTURE OF THE MINERAL RESOURCE BASE}

The article considers possible ways of geological study and development of the mineral-raw material complex of the Black Sea, in particular, the energy complex, oolite iron ores, building materials, mineral fertilizers, fresh water, titanium-zirconium, magnetite placers and thin gold. The necessity of studying and developing gas hydrates is emphasized. The importance of fundamental research for applied geology, especially the study of crystalline rocks of the Black Sea for understanding its geological history and structure is noted.

Keywords: Black Sea, mineral-raw material base, sapropels, methane gas hydrates, coastal-marine placers, thin gold. 